\title{
TRANSITIONING THE PUBLIC SPACE - THE CASE OF BELGRADE SHOPPING MALL
}

\author{
DOI: 10.18485/arh_pt.2020.7.ch17
}

\section{_ Marija Cvetković}

Teaching Assistant, University of Belgrade - Faculty of Architecture, Bulevar Kralja Aleksandra 73-II, marija.cvetkovic@arh.bg.ac.rs

\section{_ Ivan Simić}

PhD, Assistant Professor, University of Belgrade - Faculty of Architecture, Bulevar Kralja Aleksandra 73-II, ivan.simic@arh.bg.ac.rs

\section{- Aleksandar Grujičić \\ Teaching Assistant, University of Belgrade - Faculty of Architecture, Bulevar Kralja Aleksandra 73-II, aleksandar.grujicic@arh.bg.ac.rs}

\section{ABSTRACT}

The (shopping) mall is a utopian common space that aims to form new gathering places and bring people together, functioning as a "city within a city" (Gruen \& Smith, 1960; Kaliski, 2008). They are becoming new downtowns and are now ubiquitous and frequently visited places (Kowinski, 1985). Contrary to the concept of a mall being considered a non-place (Augè, 1992), it is now often viewed as one of the better-quality forms of public life in a modern city - spaces that have the highest level of attendance, and are able to function as super-places.

The emergence of shopping mall is notable after the World War II, differentiating the USA model and the European one. While in the USA the problem of traffic expansion in the use of shopping facilities was solved by placing trade facilities on the outskirts of cities adjacent to transit streets and interchanges, in Europe a controlled separation of heavy traffic was carried out, which allowed the creation of spaces synthesising the pedestrian corridors and shopping areas in the city core. The transition process has had significant consequences in the context of economic, political and social structures in the countries of Central and Eastern Europe. A visible aspect of these changes is also seen in retail organization, privatization and the formation of new trade organizations, and the opening of markets to foreign capital and international trading chains.

Presenting the examples of one characteristic shopping mall in Belgrade - Rajićeva Shopping Center - distinct by its urban extent and morphology, this paper aims to explore potential urban identity and quality of space increase in the case of newly formed semi-public spaces within open and closed areas of the mall, by analysing the spatio-physical aspect of the mall and its role in the definition of immediate urban surrounding.

KEYWORDS _ shopping mall, semi-public space, urban identity, public space quality, Belgrade 


\section{INTRODUCTION}

Trade is one of the most vital and important urban functions and as such has an important role in the emergence, development and shaping of cities, undeniably impacting the urban environment. Relationships and connections between urban structures and trade, as the cause of city development, is one of the most common explanations presented in the studies of the history and development of cities and settlements. Until the Industrial Revolution, trade was the main driver and key factor in the development of cities. Throughout history, trade has been located along the main streets or intersections of several key routes in the city, where the development of such settlements is linked exclusively to the development of trade, which requires spatial expansion of trade and results in the formation of networks of new spaces. New contents appear, which are important for the development of the city and the everyday life of the inhabitants, and those soon become the spaces of gathering and exchange of goods. Markets are considered an important functional urban space of the city, where a unique urban communication environment is created - bringing citizens together. The need for a controlled trade space soon arose, and the market was moved to covered areas, where open spaces were vacated, thus becoming city squares. The emergence of complex functions, as well as clear spatial relations in the city are one of the features of a quality urban environment. The development of the city's economy and its physical structure is intertwined, and with the growth of the city's economic power, there is a need for new types of buildings and spaces, changing the relations between the public and private spheres of life in the city.

\section{SHOPPING SPACES IN URBAN SURROUNDINGS}

By creating new forms and transforming the existing structure through the positioning of consumption space, the space of the modern city is reshaped (Dawson, 1983; Goss, 1992, 1993; Howard, 2007). Spatial relations in the traditional urban fabric are changing with the construction of new, modern spaces of the modern city. On the one hand, public spaces in traditional cities maintain their importance in city centers, while on the other hand, new "public" areas are constantly being formed within new types of buildings specific to modern society. A modern shopping center is a typical example of this type of facility. It is a building within which the public and commercial spaces of a traditional city coexist. Along with the appearance of this type of buildings in the inner city center, the traditional commercial space of the city has changed, and public spaces have become less visited and sometimes abandoned, showing that this new type of building reflects the individualistic and materialistic nature of social structure, reinstating the previous functions of public spaces.

In the modern city, the primacy of shopping spaces is taken over by large-format shopping centers. Some researchers see the emergence of shopping centers as "the culmination of human consumer nature" and "one of the biggest milestones in urban space organization" (Pušić, 2009). Shopping centers are taking precedence over the commercial and entertainment functions of the city street, and consequently, shifting the public space - bearing the networking function and the basic determinant of the spatial structure of the urban area. The evolution of the shopping center was marked by the inclusion of increasingly different contents, so these spaces became gathering and leisure time places, which justifiably gave them the epithet of social places. In recent research, the mall is no longer perceived only as a form of retail, but also as a postmodern place of consumption in which trade and leisure intertwine (Holbrook \& Jackson, 1996). Shopping malls as temples of consumerism (Debord, 1967; Mumford, 1938) and cathedrals of consumption (Ritzer, 2005; Goss, 1993; Kowinski, 1985; Sikos \& Hoffmann, 2004) are becoming new centers of social life - a place of socialization, trade, spectacle and information exchange. Despite its intrusive individualistic ideology, the shopping center provides a venue, generates motivation for audience visits, where shopping and leisure activities merge into a unique time of consumption, while the space itself has become a place of gathering and social liveliness (Bloch, 1983, 89, 94; Sit, 2003; Howard, 2007).

The shopping mall is viewed as an integral part and one of the essential components of the immediate urban environment. Such facilities are specific places in terms of design, content and func- 
tions, sociability and meaning, therefore it is important to determine which aspects of the urban environment are impacted with this facilities. The quality of the urban environment depends on several factors, which have been discussed in the professional literature of the past few decades, where there are sets of criteria and characteristics of urban space quality proposed by different authors (Lynch, 1960; Jacobs, 1961; Jacobs, Appleyard, 1987; Bentley, 1985; Whyte, 1988; Tibbalds, 1988, 1992; Francis, 2003; Carmona et al, 2003; CABE, 2000, 2004, 2006). Of all the above criteria, the most important factors for evaluating the quality of the urban environment can be systematized in four specific groups of quality factors of the urban environment: physical (continuity, legibility, visual suitability, permeability); functional (flexibility, vitality, diversity, usability); social (inclusiveness, sociability, control, convenience); symbolic (peculiarity, authenticity, attractiveness, perceptiveness).

_ Table 1: Quality factors of the urban environment

\begin{tabular}{|c|c|c|}
\hline \multicolumn{2}{|c|}{$\begin{array}{l}\text { quality factors of the } \\
\text { urban environment }\end{array}$} & description \\
\hline \multirow{4}{*}{ 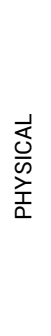 } & continuity & $\begin{array}{l}\text { integration of mall space into the existing structure of the urban environment; spatial } \\
\text { and dispositional relation to the environment; continuity in pedestrian and traffic flows }\end{array}$ \\
\hline & legibility & $\begin{array}{l}\text { a place with an easily understandable, logical and clear structure and network of links } \\
\text { and content, with clear paths and connection points, physically accessible to all users. }\end{array}$ \\
\hline & visual suitability & $\begin{array}{l}\text { aesthetic quality of space. fitting - connecting - visual adequacy and appropriate } \\
\text { shaping and materialization }\end{array}$ \\
\hline & permeability & $\begin{array}{l}\text { permeability quality can be measured by the number of alternative and basic pathways } \\
\text { through the urban environment; ease of movement; creating responsive places }\end{array}$ \\
\hline \multirow{4}{*}{ 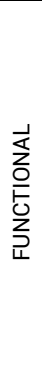 } & flexibility & $\begin{array}{l}\text { a place that easily adapts to changing user requirements and technological and } \\
\text { economic conditions; a space that can be modified, transformed and adapted to a } \\
\text { variety of functions and activities; user participation in changing the physical structure } \\
\text { of the place }\end{array}$ \\
\hline & vitality & $\begin{array}{l}\text { ecological sustainability of space; sustainable places that meet local needs; the degree } \\
\text { to which the design of the space supports the functions, biological and environmental } \\
\text { conditions, as well as the abilities of the users; }\end{array}$ \\
\hline & diversity & $\begin{array}{l}\text { diversity and appropriate combination of content, activities and services; space } \\
\text { structure should invite and encourage public life, to provide multifunctional space and } \\
\text { diversity of users }\end{array}$ \\
\hline & usability & a clear and functional space that contains all the necessary elements for functioning \\
\hline \multirow{4}{*}{$\begin{array}{l}\frac{1}{\mathrm{~L}} \\
\mathrm{O}\end{array}$} & inclusiveness & $\begin{array}{l}\text { environment that is available and accessible to all; a space that encourages } \\
\text { communication between different cultural groups; user participation allows } \\
\text { personalization of the place }\end{array}$ \\
\hline & sociability & $\begin{array}{l}\text { creating a meeting place and a sense of community, a place that provides an } \\
\text { opportunity for user interaction and receptivity; spaces that encourage citizen } \\
\text { participation in social and public life through passive and active involvement }\end{array}$ \\
\hline & control & $\begin{array}{l}\text { clean space with a high level of maintenance; space users can create and manage } \\
\text { access to space and activities; a safe, well-lit and marked area }\end{array}$ \\
\hline & convenience & $\begin{array}{l}\text { comfortable spaces that enables basic human needs; furniture that provides space for } \\
\text { relaxation and enjoyment, meetings and activities }\end{array}$ \\
\hline \multirow{4}{*}{$\sum_{\substack{0\\
}}^{0}$} & peculiarity & $\begin{array}{l}\text { a place with its own identity and character; a sense of individual or collective belonging } \\
\text { to the environment; user involvement to increase a sense of belonging }\end{array}$ \\
\hline & authenticity & $\begin{array}{l}\text { clear meaning and image of space; thematization of space; creating a recognizable } \\
\text { identity; the authenticity of the spatial structure and architectural composition }\end{array}$ \\
\hline & attractiveness & $\begin{array}{l}\text { creating certain benchmarks that define the look, provide a recognizable meeting } \\
\text { space; a place that attracts users and provides space for creativity }\end{array}$ \\
\hline & perceptiveness & understanding the context of the area; symbolism and memory places \\
\hline
\end{tabular}




\section{Emerging Megastructures - Shopping Malls}

It is noticed in recent literature that shopping malls are presented as new city centers from both the physical-functional and the social aspect. These are spaces that users perceive as new gathering places, where various events are organized, where it is possible to find all the necessary things under one roof and in one place - similar to the urban city center. According to Victor Gruen, the designer of the first shopping centers, these facilities are "a vehicle that leads to the intention to redefine the modern city." He believes that the "mall" is a place of utopian common space that aims to gather and bring people together, he considers the "mall" a new city. Contrary to the concept where the mall is considered a non-place (Augè, 1992), they are now often seen as one of the better forms of public life in the modern city, ie spaces that have the highest attendance in the city and are able to function as super- places. Kowinski believes that shopping malls have become new centers of the city and today ubiquitous and frequently visited places (Kowinski, 1985). With their appearance, shopping malls give the impression of glass boxes of various contents, implying generic design. These facilities are characterized by a higher degree of comfort, security, concentration of activities and content, they become better, more acceptable and more attractive places of socialization. The result is new (public) spaces that become interesting to the capital.

\section{Geographical Varieties}

Observed from the socio-cultural aspect, where culture is a complex of beliefs of society, its role, tradition and customs, it is possible to notice that within the object (being a product of globalism), one can recognize cultural heritage and traditions of a region, habits and customs of consumers. Such features significantly affect the design and visual identity of objects. A notable difference can be observed in facilities in different geographical areas, such as the Middle East, the USA and Europe. There is a difference in the concept of a shopping center in American and European cities. Urban conditions related to trade facilities after World War II in Europe were quite different from those in the United States, while a common factor for both areas was the growth of automobile traffic. Social and spatial changes were manifested in the expansion of the city, ie the conversion of rural areas through urbanization and the formation of new housing units with all the necessary accompanying facilities, including trade. While in the USA the problem of traffic expansion in the use of trade facilities was solved by placing trade facilities on the outskirts of cities next to transit streets and junctions, in Europe a controlled separation of heavy traffic was carried out, which enabled the synthesis of pedestrian corridors and trade zones in urban core. The transition process has had significant consequences in the context of economic, political and social structures in the countries of Central and Eastern Europe. A visible aspect of these changes can be seen in trade, ie retail organization, privatization and the formation of new trade organizations, and the opening of the market to foreign capital and international trade chains.

\section{Post-socialist Transformations}

The characteristic of the development of post-socialist cities is that the cities went through complex changes under the conditions of post-socialist transformation, globalization and Europeanization. Socialist countries lagged behind in the domain of trade due to closedness, while in Western Europe the trade power of cities grew in the trade sector. Radical changes in the former socialist states of Central and Eastern Europe in the early 1990s created a new social, economic, spatial and cultural environment that shaped a new urban reality (Lazić, 2011). Large cities in transition countries recorded a sharp increase in retail sales in those years as a result of increased demand for consumer goods (Lukić, 2002). Market liberalization represents a systemic economic change of post-socialist society, which fundamentally changes many aspects of life and functioning, including urban forms and spatial development (Tsenkova \& Nedović-Budić, 2006). Unlike the socialist period, in the period of transition, the attitude towards the spatial distribution of non-residential contents within the city is changing. 


\section{Evolving Shopping - Belgrade Shopping Areas Between 1990s and the New Millenium}

The post-socialist period of shopping facilities includes the period of temporary facilities, street sales in the open and the first generation of shopping centers from 1990 to 2000 , such as the temporary Open Shopping Center in New Belgrade block 43, the so-called "Flea Market", which began operating in 1994 (according to the new plans, it is to be moved to a new location by 2021 next to the "Kvantaš" market). The main characteristic of that period is the sale in the open, ie on the streets (Bulevar kralja Aleksandra), flea markets, green markets, in a large number of temporary facilities and kiosks. During the "late" transition in the mid-1990s, shopping malls meet social needs and the first generation of shopping malls was created (some of which are temporary). Nowdays, they are considered unsuccessful due to the neglected solution of parking spaces. The need for "filling the space" is created and shopping centers emerge within the city blocks that are completely outside the communicative flows, such as Čumićevo sokače, Sremska, Milenijum, Staklenac, Zemunikum, City Passage and others. Lately, however, we have witnessed the recontextualization and refreshment of the sales area of Čumić's alley, which began the renovation and return to life of that ambience, with a new character and meaning for the city. Since November 2010, Čumićevo sokače has become a meeting place for local designers, buyers and fashion fans. Therefore the ambience of the first shopping center in Serbia is revived. Working on such projects opens the basic theme of reviving and transforming a city place with a specific function into a modern interactive center of design, art and complementary content.

\section{Evolved Shopping - 21st Century Belgrade Shopping Spaces}

During 2000s large modern shopping formats were formed, resulting in the emergence of shopping centers and hypermarkets. In the period of ten years - from 2001 to 2011, about 25 large trade formats appeared in Belgrade, of which 15 covered an area of 5,000 to 130,000 m2, starting the even greater expansion throughout the city. There is a need for shopping malls to effectively monitor planning mechanisms. With the opening of the market and the introduction of large capital (investors), shopping centers are nowadays located in large plots in the city and function as generators of development in the urban fabric. They are becoming signs of a modern city - function, symbolism and social roles are changing. The importance of local centers is diminishing, which is shown by the fact that "Delta City" and "Ušće shopping center", as market leaders in this category are the preferred choice than all local shopping centers combined (Djukić \& Cvetković, 2016). In addition, it should be emphasized that a good part of the sales space in the central city municipalities is located in the facilities that were built a long time ago. Namely, in these municipalities (Savski Venac and Stari Grad) there are some traditional shopping streets such a Knez Mihailova, Kralja Milana, Karađorđeva, Sarajevska and others. Since these are central city municipalities, trade was the first to develop in them.

In Belgrade, shopping malls are located in the city itself, and not on the bypass around the city, or on the outskirts of the city, as is the case in other countries, which affects the shopping facilities located in the central city center. As a result of such distribution, numerous contents from the city center become less attractive and more empty with the opening of new shopping centers. More than a decade ago, "City Passage", "Millennium", "Staklenac" and "Čumićevo sokače" were places where citizens flocked to buy clothes and shoes in the latest fashion. Today, that image can be seen only in large shopping malls such as "Ušće", "Delta City", "Rajićeva", and many others, and apart from the goods, they are also attractive to customers because of the service and entertainment facilities. New forms of trade are emerging, through the combination of various services and activities within the center, and through the "formation of a new city" - resulting in form complexity.

\section{IMPACTING THE SURROUNDINGS - THE CASE OF BELGRADE SHOPPING MALLS}

Objects that are incorporated into modern urban fabric cease to exist in the form of a static segment of urban tissue, but are integrated into the network of the urban environment and exist in synergy 
with the contents of that area. Therefore, the shopping center building is seen as an integral part of the urban environment. There is no universal definition of the term urban environment, and in existing research this term is presented through a series of interpretations and definitions, and the definition of the term depends on the context in which it is used. The character of the urban environment, according to Norberg-Schulz, is the totality of concrete things that have materiality, shape, texture and color, where these things together determine the "character of the environment", which is the essence of the place, and the concrete expression for the environment is the place (Schulz, 2003). The place is, therefore, a qualitative phenomenon of "totality", which we cannot reduce to one character trait.

This segment analzyes unique shopping mall in Belgrade - Rajićeva Shopping Center, distinct by its urban extent and morphology, exploring the potential urban identity and quality of space increase in the case of newly formed semi-public spaces within open and closed areas of the mall, by analysing the spatio-physical aspect of the mall and its role in the definition of immediate urban surrounding. Basic contextual characteristics are presented for this shopping center, while their relation and impact to the quality factors of the urban environment are summarized in four separate groups: physical, functional, social and symbolic. Sub factors are then used to form detailed qualitative impact and valuate the potential increase of urban identity and quality of space corelating with immediate urban surrounding.

\section{RAJIĆEVA Shopping Center}

The project of the hotel-business complex in Rajićeva 82 is located in the municipality of Stari Grad in the central city area in the traditional city matrix, at an altitude of about 116 meters. The facility is located in a densely built urban environment, in the main city pedestrian zone near Kalemegdan Park. The complex was designed by the author team of Milan and Vladimir Lojanica at the end of the 20th century as an integrated and non-invasive system of buildings fused into an organic whole in the area of the former trolleybus turnpike at the end of the main city pedestrian street Kneza Mihaila. More than twenty years ago, this project won the first prize in a competition of thirty-five author teams at a public architectural and urban competition. The project task of the competition was the urban transformation of the existing state of the city block in the historic core, filling the empty, decomposed location with inconspicuous gables in the exposed reverse of the city block, with multifunctional contents emphasizing commercial content.
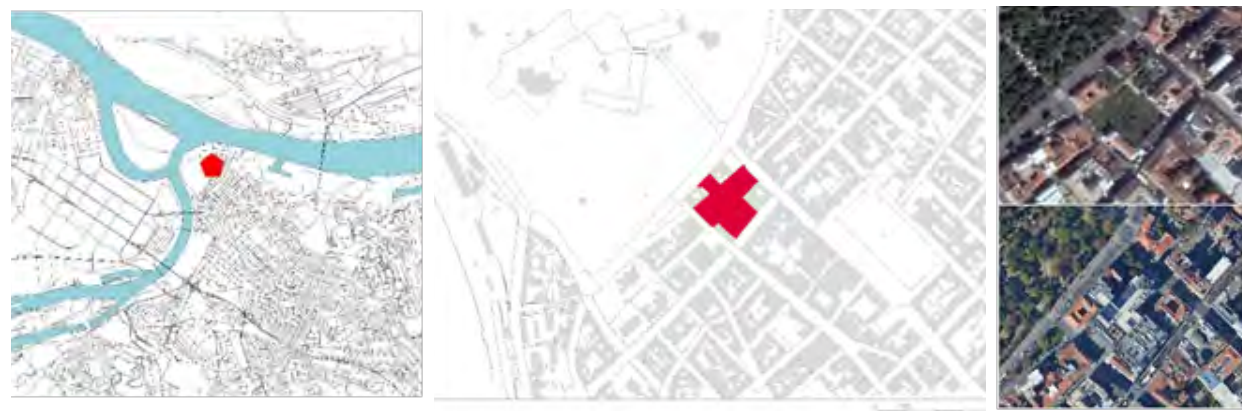

_ Figure 1: Position of shopping mall Rajićeva in the city matrix. Source: author. Right: Ortophoto image of shopping mall Rajićeva 2014 and 2018. Source: Google Earth

Within this complex, which was created by block interpolation, the purposes of a predominantly commercial character are represented: trade, business, service and hotel facilities, and in the underground floors there is a space for stationing vehicles, as well as the space of the city library depot. The project strives to fit into the traditional city core and local cultural heritage by combining the new and the old, and with its spatial concept and architectural design, this building unites the entire city block into a single communication structure. A square has been formed in front of the building 
towards the pedestrian street, which connects the contents of the complex and the public space of the pedestrian zone. It is also important to emphasize that the shopping center is located on the archeological finds of the Roman Singidunum. The excavated artifacts are exhibited in situ in the glass pools of the entrance to the shopping center in Knez Mihailova Street, which makes it even more attractive (Plemić, 2018).

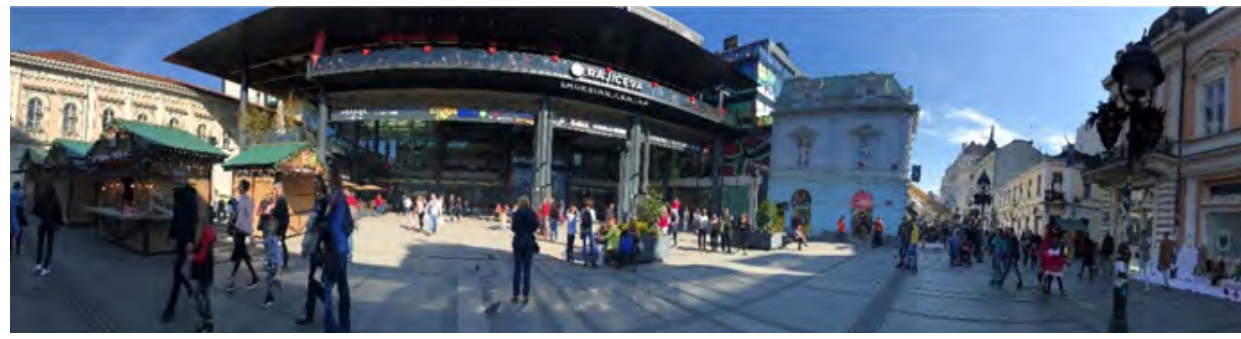

_ Figure 2: Panoramic image of shopping mall Rajićeva. Source: author.

There was a lot of controversy in the professional public about whether this building has a place in a protected environment at all (Maldini, 2017), believing that this building threatens and inadmissibly changes the existing values of the previously created urban matrix and environment, and that the building in significant conflict with the urban image of that part of the center of Belgrade.

_ Table 2: Quality factors of the urban environment in the case study of Rajićeva Shopping Center

\begin{tabular}{|c|c|c|}
\hline \multicolumn{2}{|c|}{$\begin{array}{l}\text { quality factors of the } \\
\text { urban environment }\end{array}$} & description \\
\hline \multirow{4}{*}{ 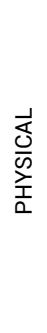 } & continuity & $\begin{array}{l}\text { integration of mall space into the existing structure of the urban environment; spatial } \\
\text { and dispositional relation to the environment; continuity in pedestrian and traffic flows }\end{array}$ \\
\hline & legibility & $\begin{array}{l}\text { a place with an easily understandable, logical and clear structure and network of links } \\
\text { and content, with clear paths and connection points, physically accessible to all users. }\end{array}$ \\
\hline & visual suitability & $\begin{array}{l}\text { aesthetic quality of space. fitting - connecting - visual adequacy and appropriate } \\
\text { shaping and materialization }\end{array}$ \\
\hline & permeability & $\begin{array}{l}\text { permeability quality can be measured by the number of alternative and basic pathways } \\
\text { through the urban environment; ease of movement; creating responsive places }\end{array}$ \\
\hline \multirow{4}{*}{ 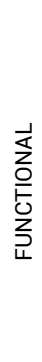 } & flexibility & $\begin{array}{l}\text { a place that easily adapts to changing user requirements and technological and } \\
\text { economic conditions; a space that can be modified, transformed and adapted to a } \\
\text { variety of functions and activities; user participation in changing the physical structure } \\
\text { of the place }\end{array}$ \\
\hline & vitality & $\begin{array}{l}\text { ecological sustainability of space; sustainable places that meet local needs; the degree } \\
\text { to which the design of the space supports the functions, biological and environmental } \\
\text { conditions, as well as the abilities of the users; }\end{array}$ \\
\hline & diversity & $\begin{array}{l}\text { diversity and appropriate combination of content, activities and services; space } \\
\text { structure should invite and encourage public life, to provide multifunctional space and } \\
\text { diversity of users }\end{array}$ \\
\hline & usability & a clear and functional space that contains all the necessary elements for functioning \\
\hline
\end{tabular}




\begin{tabular}{|c|c|c|}
\hline \multirow{4}{*}{ 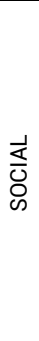 } & inclusiveness & $\begin{array}{l}\text { environment that is available and accessible to all; a space that encourages } \\
\text { communication between different cultural groups; user participation allows } \\
\text { personalization of the place }\end{array}$ \\
\hline & sociability & $\begin{array}{l}\text { creating a meeting place and a sense of community, a place that provides an } \\
\text { opportunity for user interaction and receptivity; spaces that encourage citizen } \\
\text { participation in social and public life through passive and active involvement }\end{array}$ \\
\hline & control & $\begin{array}{l}\text { clean space with a high level of maintenance; space users can create and manage } \\
\text { access to space and activities; a safe, well-lit and marked area }\end{array}$ \\
\hline & convenience & $\begin{array}{l}\text { comfortable spaces that enables basic human needs; furniture that provides space for } \\
\text { relaxation and enjoyment, meetings and activities }\end{array}$ \\
\hline \multirow{4}{*}{$\begin{array}{l}\frac{\cup}{\vec{J}} \\
\sum_{\dot{\infty}}^{\infty} \\
\sum_{\infty}^{\infty}\end{array}$} & peculiarity & $\begin{array}{l}\text { a place with its own identity and character; a sense of individual or collective belonging } \\
\text { to the environment; user involvement to increase a sense of belonging }\end{array}$ \\
\hline & authenticity & $\begin{array}{l}\text { clear meaning and image of space; thematization of space; creating a recognizable } \\
\text { identity; the authenticity of the spatial structure and architectural composition }\end{array}$ \\
\hline & attractiveness & $\begin{array}{l}\text { creating certain benchmarks that define the look, provide a recognizable meeting } \\
\text { space; a place that attracts users and provides space for creativity }\end{array}$ \\
\hline & perceptiveness & understanding the context of the area; symbolism and memory places \\
\hline
\end{tabular}

\section{CONCLUSIONS}

The urban environment in modern civilization is largely subordinated to the visions of designers and investors in the construction sector. The role of architectural and urban design, based on design principles through systematized education and technological conditioning, is to subordinate these visions to the user and improve the quality of the facility, space and area in which the project is located. A historical review of shopping complexes indicates the exponential growth of shopping center facilities in the world, with an emphasis on the increasing multifunctionality and adaptability of these spaces.

The case of Belgrade on the other hand shows a tendency to develop shopping centers in the central city areas with the characteristics of buildings that, with their size, shape and functional structure, are more suitable for areas in the residential tissue or the outskirts of the city. Such positioning is a consequence of the political, institutional and economic aspects of development, as well as the so-called investor urbanism, which is manifested by a series of physical, functional and social consequences on the quality of the immediate urban environment. Therefore, there is a need for precise definition of the concepts of the urban surroundings, as well as the identification of urban environment quality factors as the initial theoretical determinants for defining models for evaluating the impact of the shopping center on the urban environment. The following are defined as general factors for evaluating the quality of the urban environment: continuity, readability, visual suitability, permeability, flexibility, vitality, diversity, usability, inclusiveness, sociability, control, comfort, peculiarity, authenticity, attractiveness and perceptiveness. By analyzing the context of the location in which the shopping center is positioned, certain spatial preconditions for the positive effect of the building on the immediate urban environment from the point of view of urban development have been noticed.

Multiple contribution to the quality of the immediate environment is achieved by open areas through their potential to create adequate spatial conditions for different types of permanent and occasional leisure activities. In the current conditions, there is a trend of marginalization and degradation of the quality of open public areas of the city. Neglecting the adequate design of open spaces within trade facilities, which are considered to be somewhat new social centers of the city, leads to a progressive decline in the quality of the immediate urban environment. The paper points out the importance of the affirmation of open public areas in front of the shopping center as fundamental components of the urban fabric, which have a direct impact on the quality of life of users in these areas. In this regard, the interdependence of basic human needs and the quality of open public spaces is of particu- 
lar importance for this work. In addition, the potential of these spaces is important for the realization of spatial-ambient and symbolic values of space.

The research of the derived characteristics in selected shopping center in Belgrade confirmed that the impact of the building on the quality of the immediate urban surrounding changes depending on the characteristics of the building. It was concluded that buildings that respect the historical and aesthetic values of the environment, which are integrated into the existing pedestrian flows and their design open to the urban environment have a positive effect on the immediate urban environment, maintaining the current identity of the place, or slightly creating a new one.

\section{ACKNOWLEDGEMENTS}

The article is realized as part of the project "Studying climate change and its influence on the environment: impacts, adaptation and mitigation" (43007) financed by the Ministry of Education and Science of the Republic of Serbia within the framework of integrated and interdisciplinary research for the period 2011-2020.

\section{REFERENCES}

- Augé, M. (1992) Non-places: introduction to an anthropology of supermodernity,. London, Verso, 2008. (prevod: Ože, M. (2005) Nemesta: Uvod u antropologiju nadmodernosti. Beograd: Biblioteka XX vek.) - Bentley, L., Alcock, A., Murrain, P., McGlynn, \& S., Smith, G. (1985). Responsive Environments: A Manual for Designers. Architectural Press, London _ Bloch, P. H. \& Richins, M. L. (1983). Shopping Without Purchase: An Investigation of Consumer Browsing Behavior, Advances in Consumer Research, 10, 389-393.

- Bloch, P. H., Ridgway, N. M. \& Sherrel, D. L. (1989). Extending the concept of shopping: An investigation of browsing activity. Journal of Academy of Marketing Science, 17 (Winter), 13-21.

- Bloch, P., Ridgway N. \& Dawson, S. (1994). The Shopping Mall as Consumer Habitat, Journal Retailing, Volume 70 , Number 1, pp. 23-42.

- CABE (2006) Design review How CABE evaluates quality in architecture and urban design, London

_ CABE (Commission for Architecture and the Built Environment), (2004), The value of public space, London

- Carmona, M., Heath, T., Oc, T. \& Tiesdell, S. (2003) Public Places - Urban Space: The Dimensions of Urban Design. The Architectural Press: Oxford.

- Dawson, J. (1983). Shopping centre development. London: Longman

- Debor, G. (1967). Društvo spektakla. Београд: Clio

- Djukić, A. \& Cvetković, M. (2016). Shopping Mall vs. Open Public Space in Consumer Culture, Conference proceedings from International conference on urban planning. ICUP2016, Faculty of civil Engineering and Architecture, University of Niš, pp. 159 - 169, 978-88601-22-1, Serbia, 18. - 19. Nov, 2016

- Francis, M. (2003): Urban open space - Designing for user needs, Island Press, Washington

_ Goss, J. (1992). Modernity and postmodernity in the retail built environment. Ways of seeing the world, (ed. F. Gayle and K. Anderson). London: Unwin Hyman.

_ Goss, J. (Mar., 1993). The "Magic of the Mall":An Analysis of Form, Function, and Meaning in the Contemporary Retail Built Environment, Annals of the Association of American Geographers, Vol. 83, No. 1., pp 18-47.

- Holbrook, B., Jackson P (1996). The Social Milieux of Two North London Shopping Centers, Gofirum 27 (2), 193-204

- Howard, E. (2007). New shopping centres: is leisure the answer?, International Journal of Retail \& Distribution Management. Vol. 35 Issue: 8, pp.661-672,

- Jacobs, A. \& Appleyard, D. (1987). Towards an urban design manifesto: A prologue. Journal of the 
American Planning Association, Volume 53, Issue 1, pp.112-120

_ Jacobs, J. (1961). The Death and Life of Great American Cities. New York: Random House.

_ Kowinski, W. S. (1985). The malling of America: an inside look at the great consumer paradise. New York: W. Morrow.

_ Lazić, M. (2011). Postsocijalistička transformacija i restratifikacija u Srbiji. Filozofski fakultet Sveučilišta u Beogradu, Beograd, Srbija

_ Lukić, A. (2002). Socijalne funkcije trgovačko - poslovnog središta: primjer Centra Kaptol u Zagrebu. Hrvatski geografski glasnik, 64, 73 - 94

- Lynch, K. (1960). The Image of The City, Cambridge, Massachusets: The MJ.T.Press.

_ Maldini, S. (2017) Dnevnik zabluda: izgubljeni arhitektonski dragulji. Online edition of "Novosti", from 09.09.2017 (accesed: 15.01.2020).

- Mumford, L. (1938). The culture of the cities, A harvest book, NY

_ Norberg-Schulz, C. (2003). The Phenomenon of Place, in Alexander R. Cuthbert ur., Designing of Cities: Critical Readings in Urban Design, Malden, Blackwell Publishers Ltd.

_ Plemić, B. (2018). Roman remains in Rajićeva shopping centre: A new tourist attraction in Belgrade or a case study in devastation of cultural heritage? Turisticko poslovanje. 2018. 5-12. 10.5937/TurPos1821005P.

_ Pušić, Lj. (2009). Grad bez lica. Novi Sad: Mediterran Publishing.

_ Ritzer, G. (2005). Enchanting a Disenchanted World: Revolutionizing the Means of Consumption.

- Sikos T., T. \& Hoffmann, M. (2005). Typology of shopping centres in Budapest. Case Studies. 1. 24.

_ Sit, J., Merrilees, B. \& Birch, Dawn. (2003). Entertainment-seeking shopping centre patrons: the missing segments. International Journal of Retail \& Distribution Management 31(2), pp. 80-94

- Tibbalds, F. (1988). Mind the Gap. The Planner, 11-15.

_ Tibbalds, F. (1992): Making People Friendly Towns: Improving the public environment in towns and cities, Longman, Harlow

- Tsenkova \& Nedović-Budić (2006). Urban Mosaic of Post-Socialist Europe - Space, Institutions and Policy (str. 231-252). Heidelberg: Physica-Verlag, Springer.

- Whyte, W. H. (1988). City: Rediscovering the center. New York: Doubleday. 